\title{
Basidiomycetes at the timberline in Lapland 4. Postia lateritia n. sp. and its rust-coloured relatives
}

\author{
PERTTI RENVALL
}

\begin{abstract}
RENVALL, P. 1992: Basidiomycetes at the timberline in Lapland 4. Postia lateritia n. sp. and its rust-coloured relatives - Karstenia 32:43-60.

The taxonomy of the Postia fragilis group (polypores, Basidiomycetes) is revised and three species are recognized in North Europe: $P$. fragilis (Fr.) Jül., $P$. leucomallella (Murr.) Jül. and $P$. lateritia Renvall n. sp. The species are described and illustrated, and the Finnish distributions are mapped. The first two species are widespread in Europe and in North America. P. lateritia is a saprotrophic polypore here reported from Finland, Sweden and Canada. It is associated with a brown rot and has been found almost exclusively on decorticated windfalls of Pinus sylvestris L. in old forests of coniferous trees. A neotype is selected for Polyporus fragilis Fr. and the status of the genus Postia Fr. is reviewed and it is considered to be validly published; the genus Oligoporus Bref. is accepted in a restricted sense to comprise species which have short and often cyanophilous spores and which tend to produce chlamydospores. The new combination Postia septentrionalis (Vampola) Renvall is proposed and the identity of Leptoporus lowei Pilát (Oligoporus lowei (Pilát) Gilb. \& Ryv.) is discussed.
\end{abstract}

Key words: Distribution, Finland, Oligoporus, polypores, Postia lateritia, Postia septentrionalis, taxonomy.

Pertil Renvall, Finnish Museum of Natural History, Botanical Museum, Mycological Division, University of Helsinki, Unioninkatu 44, SF-00170 Helsinki, Finland

\section{Introduction}

The ferruginous polypores in the genus Tyromyces P. Karsten s. lat. have repeatedly been subject to profound taxonomical and nomenclatural discussions (Lowe \& Lundell 1956, Kotlaba \& Pouzar 1964, Donk 1960, 1972, 1974, Ryvarden 1991). Much of the debate was caused by the lack of authentic material of the recognized species and, on the other hand, most of the old names have remained untypified. The strong variability of the basidiocarps and the lack of striking microscopical characters have enhanced difficulties in obtaining correct interpretations of the old species names, such as Polyporus fragilis Fr., P. mollis Pers.: Fr., and $P$. trabeus Rostk. As already shown by Donk (1960) and recently clearly demonstrated by Ryvarden (1991), not only the species names but also the generic concepts are strongly engaged with this nomenclatural debate.

The typification of Polyporus mollis by Ryvarden (1991) fixed the meaning of that name for a brown- rot-causing polypore with a monomitic hyphal system and simple-septate generative hyphae. Hopefully it will also put an end to the discussion on the generic type of Leptoporus Quél. (see Donk 1960, Teixeira 1983, 1986, Ryvarden 1991), and Donk's (1960) conclusion that Polyporus mollis is the type species of the genus will be universally accepted. The identity of $P$. fragilis has for a long time been fairly uniformly understood (Fries 1828, Bourdot \& Galzin 1928, Bondartsev 1953, Gilbertson \& Ryvarden 1987) and the striking colour change in its bruised basidiocarps has enabled an easy identification. This is despite the fact that the species name lacks the typification. One reason for the established interpretation may be that an illustration named by Fries (1884) himself has been available. On the other hand, evidently because of the variability, the species has been described several times anew and, e.g., Donk $(1972,1974)$ and Kotlaba (1975) have revealed many synonyms for the species. 
However, many manuals provide a note on the strong variability of this taxon, and evidently because of the striking key character, the colour change, the microscopy of $P$. fragilis has received little attention.

I here revise the taxonomy of the Postia fragilis group in North Europe. In addition to the well-known species $P$. fragilis and $P$. leucomallella (Murr.) Jül., a new species $P$. lateritia Renvall is recognized. The Finnish distributions of the species are mapped, and because of the similarity of these species descriptions and illustrations of each of them are presented and a neotype is selected for Polyporus fragilis. In addition, the identity of Leptoporus lowei Pilát (Oligoporus lowei (Pilát) Gilb. \& Ryv.), a species often linked with these taxa, is outlined, and the status of the genus Postia Fr. is discussed.

\section{Materials and methods}

All the specimens of Postia fragilis, P. leucomallella and Oligoporus lowe $i$ were checked in the herbaria $\mathrm{H}$, HFR, JOE, KUO, OULU, TUR (abbreviated according to Holmgren et al. 1990) and in the personal herbaria of Heikki Kotiranta (abbreviated as H.K.), Tuomo Niemelä (T.N.), Reijo Penttilä (R.P.) and the author (P.R.), and the distribution maps are based on this material. In addition, specimens in GB-J.E. (the collections established by Dr. John Eriksson, Department of Systematic Botany, University of Gothenburg) and in UPS were studied.

160 specimens of Postia fragilis, 90 specimens of $P$. lateritia and 136 specimens of $P$. leucomallella were studied under microscope. The types of eight species names which have been considered to be synonyms of $P$. fragilis or $P$. leucomallella were studied as well, and will be discussed under each accepted taxon or in the section Excluded taxa. Microscopical characters were studied with the microscope Leitz Dialux 22 at magnifications up to $\times 1250$. Anatomical details were drawn by using the Leitz drawing tube. The chemical reagents used in the microscopical examination and their reactions are those listed by Niemelä (1985a, b). I have used Cotton Blue (CB) when drawing figures and when making microscopical measurements.

I followed the statistical recommendations of Parmasto and I. Parmasto (1987), and for the species described here 30 basidiospores were measured in each out of ten selected specimens. In addition, variable amounts of spores were measured from further specimens. In presenting the variation of the basidiospore (basidium, cystidium, hyphal) size, $5 \%$ of the measurements have been excluded from each end of the range, and are given in parentheses. Basidia, basidio- les, cystidia and cystidioles were measured to the nearest $0.5 \mu \mathrm{m}$. In the text the following abbreviations are used: $\mathbf{L}=$ the mean spore length (arithmetical mean of all the spores, in $\mu \mathrm{m}), \mathbf{W}=$ the mean spore width (arithmetical mean of all the spores, in $\mu \mathrm{m}$ ), $\mathbf{Q}$ $=$ quotient of the mean spore length and the mean spore width $(\mathrm{L} / \mathrm{W}$ ratio; variation of the specimen means), $(n=x / y)=x$ measurements of spores (basidia, cystidia, hyphae) from y specimens, ! = type specimen examined in microscope.

\section{Key to the species}

1 Hymenium with gloeocystidia; ferruginous colour change nonexistent, or very slow and weak Postia leucomallella

- Hymenium without gloeocystidia; colour of the basidiocarp often changing rapidly to ferruginous on bruising and subsequent drying ..................... 2

2 Basidiospores $3.9-5 \times 1.7-2.1 \mu \mathrm{m}$, phaseoliform; contextual hyphae arranged in radial strands; hyphae at the pileal surface mostly thinwalled and agglutinated in indistinctly yellowish to brownish bundles ................................ P. fragilis

- Basidiospores 4.5-5.9 x 1.2-1.6 $\mu \mathrm{m}$, allantoid; contextual hyphae spaced, interwoven, without orientation; hyphae at pileal surface thick-walled and with distinct ferruginous pigmentation, arising from context separately ................. P. lateritia

\section{Postia lateritia Renvall n. sp. - Figs. 1, 2}

Carpophorum annuum, effuso-reflexum vel effusum, parvum, tenue, molle, ad tactum rubescente brunneum, superficic lateritium - albidum, floccosum, subtus album. Systema hypharum monomiticum. Postiae fragilis (Fr.) Jül. affinis, sed sporis angustioribus et longioribus, (4.3-)4.5-5.9(-6.3) $\mathrm{x}$ (1-) $1.2-1.6(-1.8) \mu \mathrm{m}$.

Holotypus: Finland. Pohjois-Karjala, Lieksa, Patvinsuo National Park, Autiovaara, fallen, decorticated trunk of Pinus sylvestris, mixed forest dominated by Picea abies Grid $27^{\circ} \mathrm{E}$ : 70081:6816, alt. 200m, 3.X. 1991 Tuomo Niemclä 5547, Reijo Penttilä \& Pertti Renvall (H, isotypi in DAOM and $O)$.

Basidiocarps annual, effused-reflexed with an elongated pileus along the upper edge of the tube layer, rarely pileate or totally resupinate; small and solitary, or gregarious with a few delicate patches, soft when fresh, more fragile when dry, but keeping the cottony texture almost unchanged, resupinate areas usually ellipsoid and small $(0.5-1 \times 1-2 \mathrm{~cm})$ but sometimes up to $3.5 \times 12 \mathrm{~cm}$ wide and $1-5 \mathrm{~mm}$ thick at centre. Pilei thin and flattening down under the slightest pressure, when old often collapsed, with a blunt or fairly sharp incurved margin, $0.2-11 \mathrm{~cm}$ 

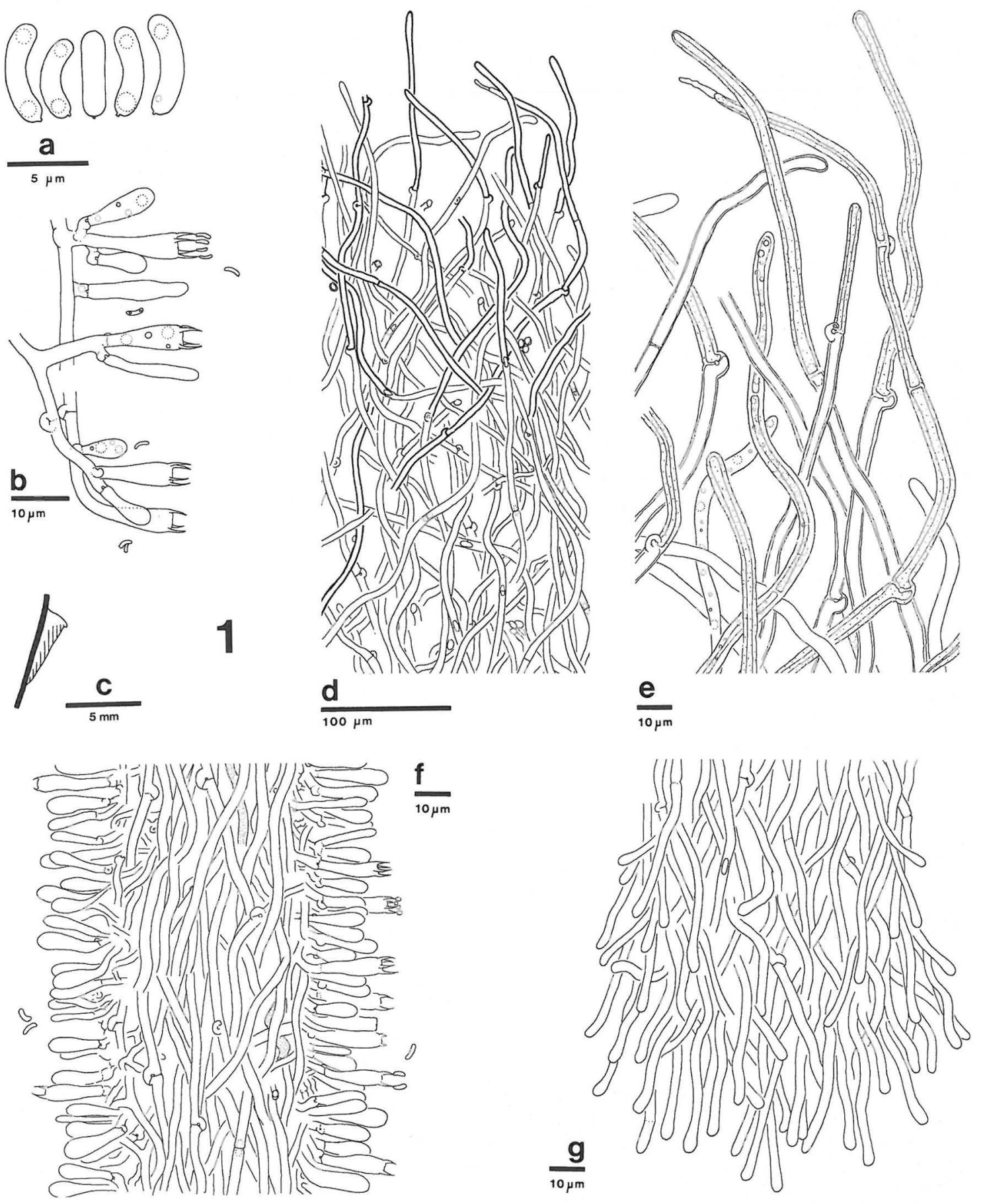

Fig. 1. Anatomical details of Postia lateritia Renvall: a) basidiospores, b) basidia, basidioles and hyphoid cystidioles, c) a section through basidiocarp, d) a section through pileael surface and upper context, e) singly arising, pigmented and thick-walled generative hyphae at the pileal surface, $\mathrm{f}$ ) a vertical section through upper dissepiment, g) dissepiment edge in a vertical section. Drawn in Cotton Blue. From the holotype $(\mathrm{H})$. 

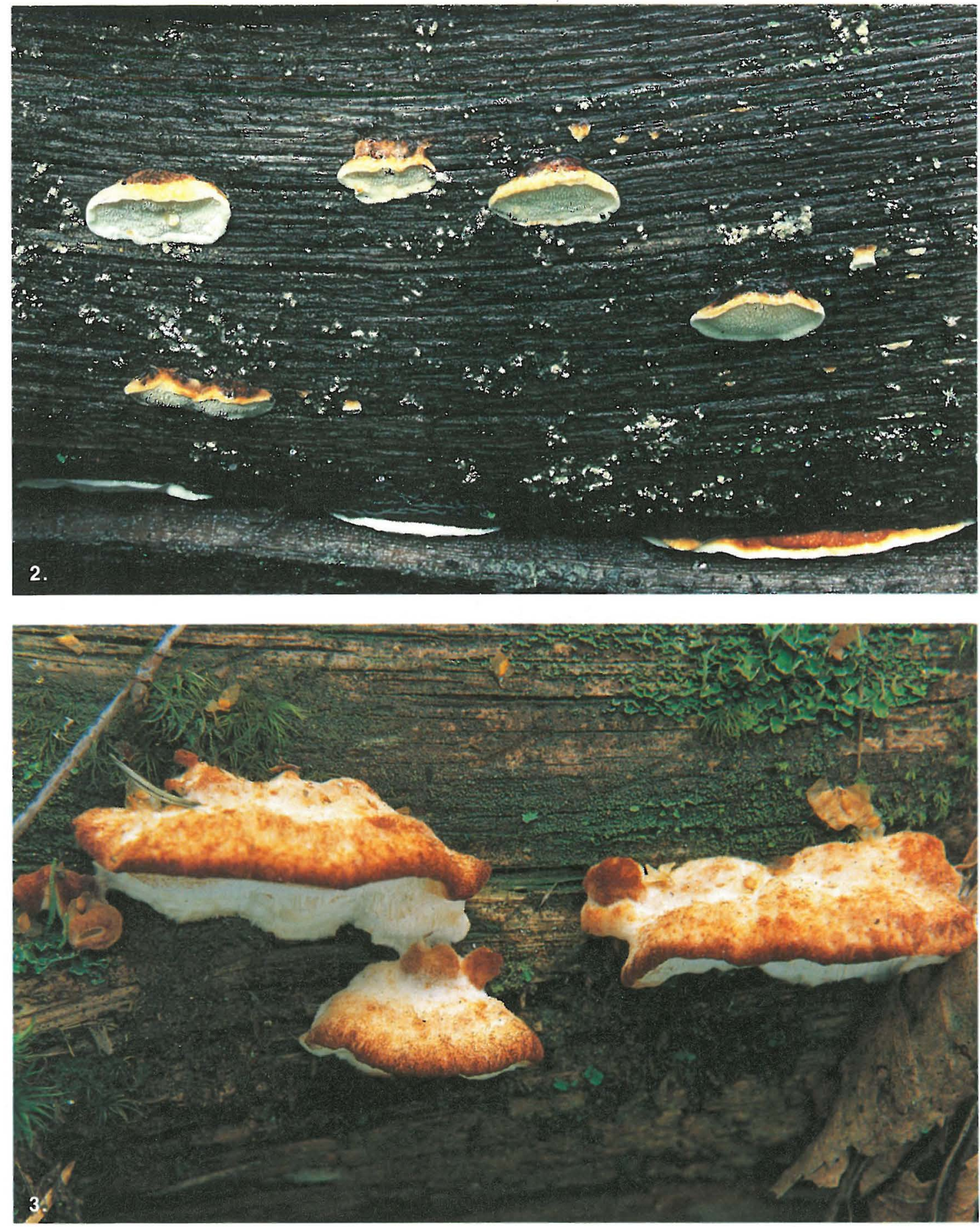

Figs. 2-3. Rust-coloured polypores of Postia Fr. Fresh basidiocarps, photographed in situ. -2 : P. lateritia Renvall, $\mathrm{x}$ 1.5. Renvall $1416(\mathrm{H}) .-3$ : P. fragilis (Fr.) Jül., $\times 2$. Niemelä $5503(\mathrm{H})$. 
wide, projecting $1-5(-15) \mathrm{mm}$ from substrate, up to 9 $\mathrm{mm}$ thick at the base, attached to an effused part. Upper surface soft, tomentose and azonate, when young basically cream-coloured, but with at least a few reddish brown dots, and changing to ferruginous when touched, when mature more evenly rusty or brick-red, after drying with slightly darker colours. Sterile margin distinct especially in resupinate parts, 0.5-1.5 mm wide, finely pubescent, white, when dry usually paler than the pores. Pore surface white when fresh, fairly rapidly changing reddish-brown on touching, when dry those parts remaining ferruginous, while unbruised parts stay white or turn cream to yellowish; pores circular to angular, variable in size, (2-)3-4(-5) per mm, walls thin, when dry ca. 0.04-0.07 mm thick; tube mouths when dry under lens ( $x$ 50) finely tomentose, when old and in bruised parts even to lacerate. Section: Context white to cream, thin, in pilei $0.5-2(-4) \mathrm{mm}$ and in subiculum up to $2 \mathrm{~mm}$ thick, soft when fresh, when dry somewhat more fragile. Tubes concolorous with the pore surface, up to $5 \mathrm{~mm}$ long.

Microscopy: Hyphal system monomitic. Context: Generative hyphae hyaline, inamyloid, indextrinoid, acyanophilous and metachromatic, thinto thick-walled, rarely branched and with frequent cross-walls and clamp connections, (2.2-)2.8-5(-6.5) $\mu \mathrm{m}$ wide $(n=193 / 10)$, loosely interwoven, without orientation but becoming more spaced towards the pileal surface, among them winding gloeoplerous hyphae, no distinct basal layer. Hyphae in the pileal surface thick-walled, with oily contents and mostly with a distinct reddish-brown to golden yellow pigmentation, often simple-septate, spaced, interwoven, arising separately from the loose context (i.e., not agglutinated), or exceptionally, in old basidiocarps, as thin strands of two or three glued hyphae. Tubes: Tramal hyphae subparallel, straight to some-what winding and rarely branched, thin- to fairly thick-walled, (1.8-)2.1-3.9(-4.8) $\mu \mathrm{m}$ wide $(\mathrm{n}=$ $217 / 10$ ), otherwise as in context; a few of them gloeoplerous. Subhymenium indistinct. Hyphal pegs frequent. Basidia slender-based, narrowly clavate, with a basal clamp, in young basidiocarps and in actively growing parts near dissepiment edges strongly bent and deep-rooting, with four sterigmata, (11.5-) $13-19(-24) \times(3-) 3.5-5(-5.5) \mu \mathrm{m}(\mathrm{n}=141 / 10)$. Basidioles slightly shorter, similar in shape. Cystidia lacking, but hyphoid cystidioles or thin-walled, cylindrical cystidioles with a finger-like apex variably present, (10-)13-22(-25) x (2-)2.5-4 $\mathrm{mm}(\mathrm{n}=44 / 9)$. Clamped hyphal ends sometimes projecting through hymenium into the tubes, rare. Basidiospores allantoid, thin-walled, smooth, hyaline, inamyloid, index-

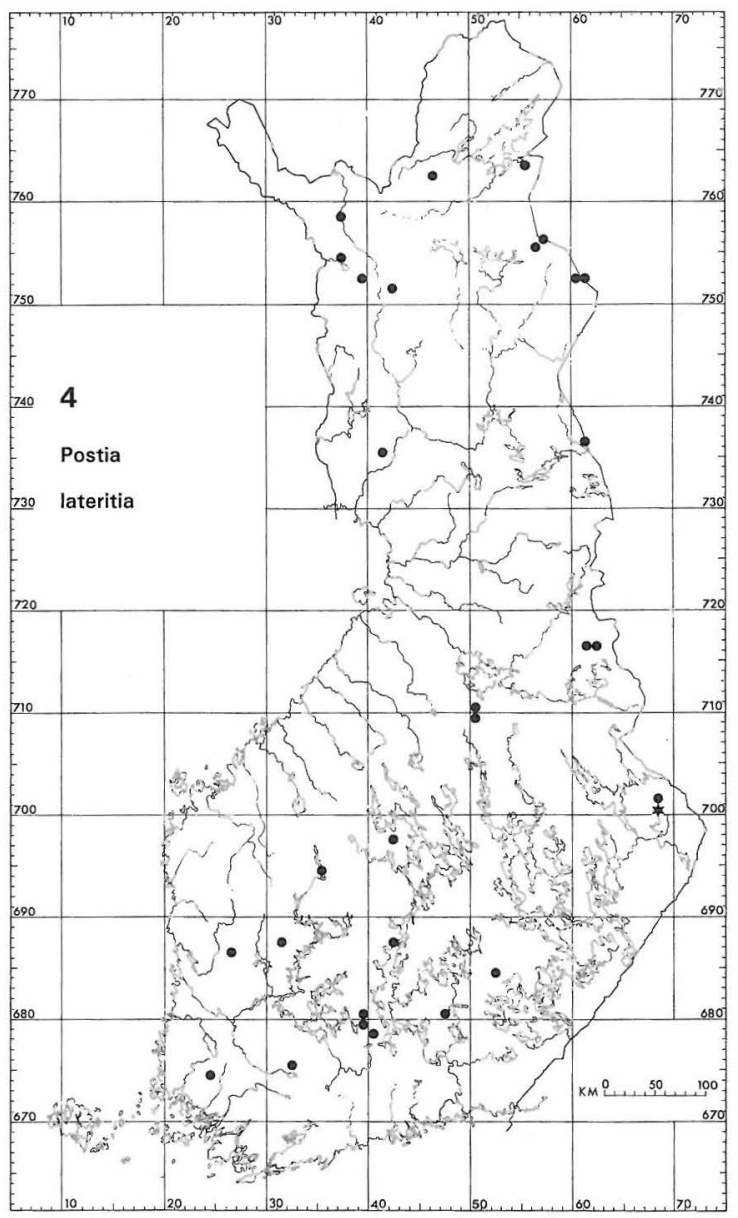

Fig. 4. The distribution of Postia lateritia Renvall in Finland according to the material examined. * = The type locality.

trinoid and acyanophilous, (4.3-)4.5-5.9(-6.3) $\mathrm{x}$ $(1-) 1.2-1.6(-1.8) \mu \mathrm{m}, \mathrm{L}=5.12, \mathrm{~W}=1.36, \mathrm{Q}=$ 3.57-3.93 $(\mathrm{n}=329 / 11)$.

Etymology: lateritius (Lat., adj.), referring to the brick red colour of the pileus.

\section{Distribution and ecology}

\section{Specimens examined}

Canada. British Columbia: McLeod Lake District, 1969 Eriksson 12212 (GB-J.E. 11228). Ontario: Algonquin Prov. Park, 1982 Hallenberg 7334 \& Ginns (GB-J.E.).

Finland. Varsinais-Suomi: Nousiainen, 1981 Kotiranta 3780 \& Koski (H.K.). Satakunta: Kankaanpää, 1940 Laurila (H). Ikaalinen, 1981 Alava 19971, Kause \& Laine (TUR), 1986 

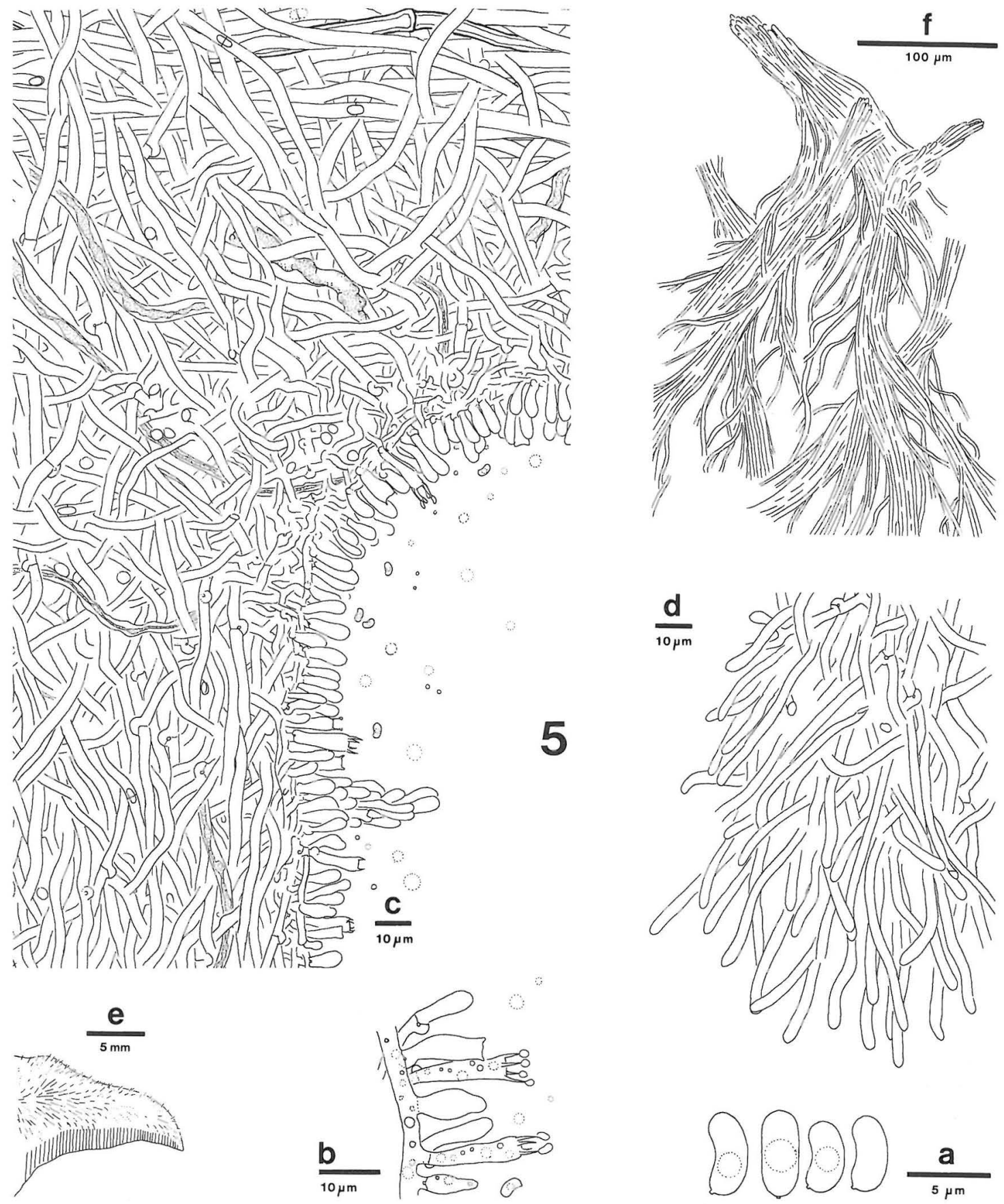

Fig. 5. Anatomical details of Postia fragilis (Fr.) Jül.: a) basidiospores, b) basidia and basidioles, c) a section through lower context and upper dissepiment showing inter alia oleiferous hyphae and a hyphal peg, d) dissepiment edge in a vertical section, e) a section through basidiocarp showing the radial orientation of contextual hyphae, f) agglutinated hyphal strands at the pileal surface. Drawn in Cotton Blue. From Niemelä $5503(\mathrm{H})$. 
Penttilä 161 (H), 434 (T.N.). Etelä-Häme: Tammela, 1866 Karsten 3479 (H), 1886 Karsten 1797 c, Karsten 3480 (H). Lammi, 1980 Kotiranta 2552 (H.K.), 1990 Renvall 2361, 2368 (H). Padasjoki, 1985 Niemelä 3303 (T.N.). Pohjois-Häme: Ähtäri, 1966 Niemelä \& Laine (HFR, T.N.). Saarijärvi, 1966 Laine \& Kurkela (HFR 022154), 1981 Kotiranta 3711 (H.K.), 1982 Kotiranta 4412, $4417(\mathrm{H}), 1984$ Kotiranta $5412,5433(\mathrm{H}), 1985$ Kotiranta $5981(\mathrm{H})$. Etelä-Savo: Mikkeli rural commune, 1964 Laine \& Poutanen B8253 (HFR 016786). Mäntyharju, 1989 Haikonen 11026 (H). Pohjois-Savo: Vieremä, 1988 Penttilä 1090 (H). Pohjois-Karjala: Lieksa, 1988 Penttilä 932, 1040, 1060 (H), 1989 Penttilä 1057, 1169, 1179, 1401, 1405, 1419, 1424 , $1439,1445,1448,1451,1452$ (H), 1439 (T.N.), 1990 Penttilä $1967 b, 1978,1982,1997(\mathrm{H}), 1991$ Niemelä 5547, Penttilä \& Renvall (holotype; H, DAOM, O), Penttilä 2646 \& Renvall 2682 (H). Kainuu: Hyrynsalmi, 1990 Penttilä 1777 (H). Kuhmo, 1991 Penttilä 2512, 2529, 2535, 2559 (H). Vuolijoki, 1989 Kotiranta 7938, Niemelä \& Penttilä $(H)$, Kotiranta 7966, Niemelä \& Penttilä (H), Kotiranta 7971, Penttilä 1500 (H). Perä-Pohjanmaa: Rovaniemi rural commune, 1980 Kotiranta 2135 \& Niemelä (H.K.), 1981 Kotiranta 3644, 3563 (H.K.), 1984 Kotiranta $5484(\mathrm{H})$. Koillismaa: Kuusamo, 1974 Ulvinen (OULU). Salla, 1987 Renvall 363, $540(\mathrm{H}), 1988$ Renvall 1088, 1170, 1261, 1262,1396 (H), 1400 (P.R.), 1416 (H), 1991 Renvall 2592 (H). Sompion Lappi: Savukoski, 1988 Renvall 1116, 1127, 1140, 1293 (H), 1331 (P.R.), 1341, 1359 (H), 1989 Renvall 1948 (H). Kittilän Lappi: Kittilä, 1970 Kurkela (HFR 022396), 1981 Kotiranta $3459(\mathrm{H})$. Muonio, 1980 Niemelä 2153 \& Kotiranta (T.N.), Kotiranta 2314 \& Niemelä (H.K.). Inarin Lappi: Inari, 1981 Kotiranta 3026 (H.K.), 1990 Kotiranta 8518 (H).

Sweden. Hälsingland: Harmånger, 1944 Eriksson 277 (UPS). Småland: Femsjö, 1929 Nannfeldt 3429 (UPS), 1940 Lundell $4112 b, 4113$ (UPS). Rumskulla, 1970 Niemelä \& Ryvarden (T.N.).

According to the present material Postia lateritia is a fairly rare boreal species occurring in dry conifer forests of Finland, Sweden and Canada. Further studies may prove that its distribution is circumboreal. This impression can be obtained from the description by Bondartsev (1953) who, when discussing $P$. fragilis, pointed out some characters which better fit the new species. In the description of $P$. leucospongia (Cooke \& Harkn.) Jül. (as Oligoporus leucospongia) Gilbertson and Ryvarden (1987) state that 'confusing intermediates between $O$. fragilis and $O$. leucospongia occur over elevational gradients in the Rocky Mountains'. This may indicate that Postia lateritia is more widely distributed in North America, but has been included either in $P$. fragilis or in $P$. leucospongia. However, Niemelä (1985b) did not find $P$. lateritia in northern Quebec, Canada.

In Finland Postia lateritia is rare in general, but locally in old protected pine forests there are fairly abundant populations left. This is true especially in the eastern and northern parts of the country (Fig. 4). The fragmented occurrence in southern Finland, in my opinion, indicates that the new species has earlier been commoner there but has decreased in number. This is evidently due to the modern forestry which

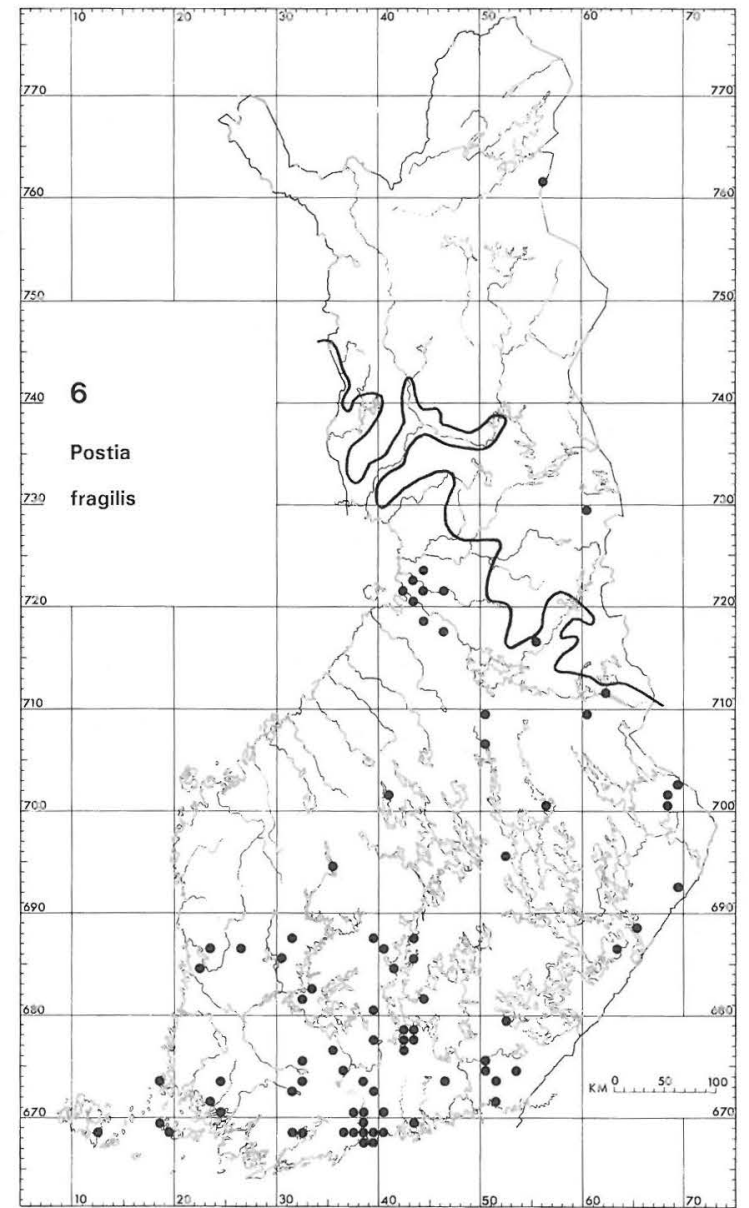

Fig. 6. The distribution of Postia fragilis (Fr.) Jül. in Finland according to the material examined. The black line indicates the southern border of the Northern Boreal vegetation zone (according to Ahti et al. 1968).

eradicates old fallen trunks of pine from most of southern and central Finland. In Finland $P$. lateritia has been found almost exclusively in forests where such trunks are left. However, its frequent occurrence in northern and eastern Finland may also indicate a preference to cooler and more continental climate.

The habitat ecology of Postia lateritia exhibits some special features. It is a saprotrophic fungus, which causes a slowly proceeding brown rot and favours fairly big fallen trunks. In Finland the species has been found exclusively in virgin or near-climax conifer forests, on fallen trunks of Pinus sylvestris. The Finnish finds derive almost exclusively from pines, which had died and lost their bark but remained standing for decades before falling down. Such trunks 


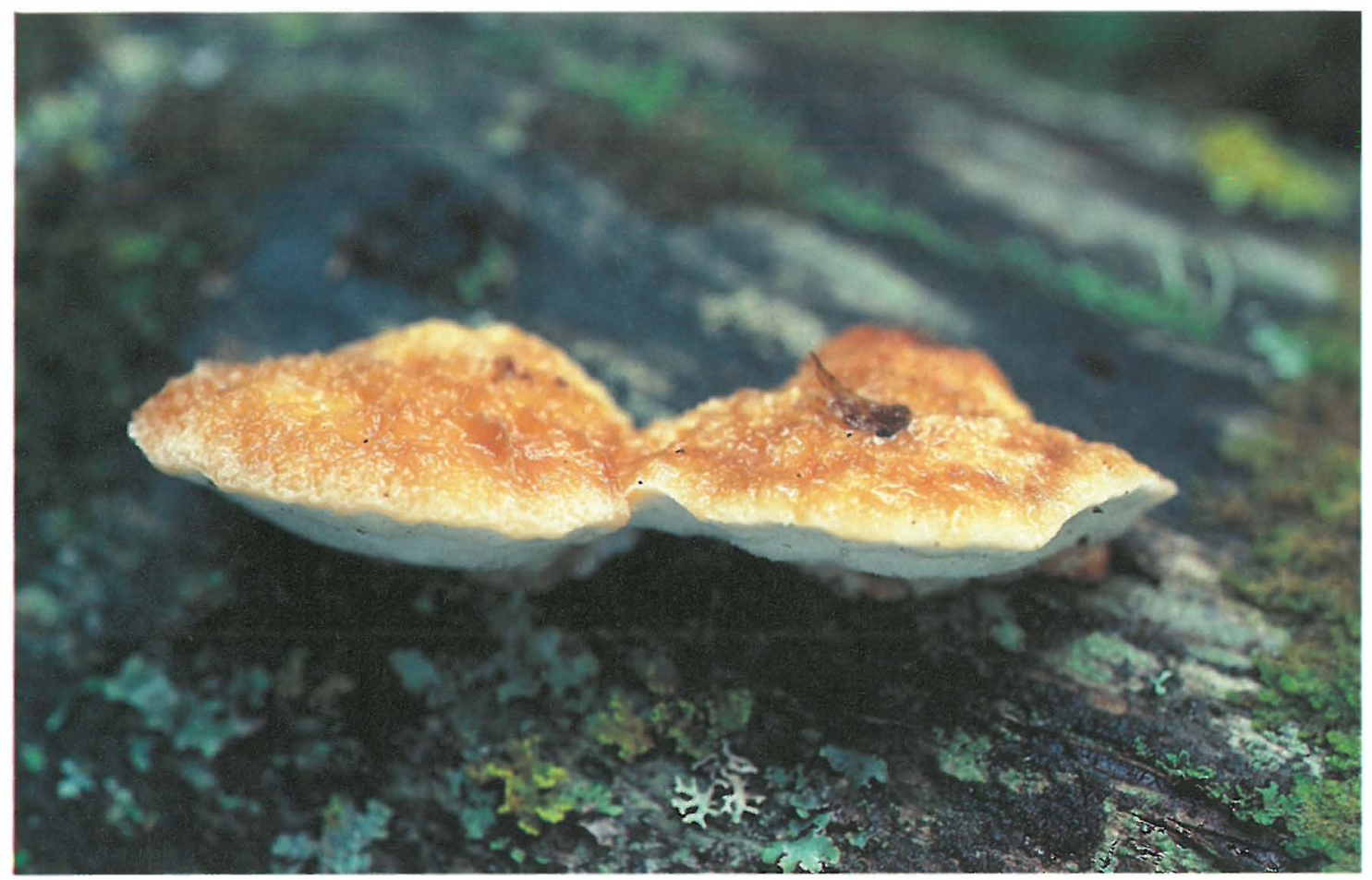

Fig. 7. A fresh basidiocarp of Postia leucomallella (Murr.) Jül., photographed in situ, x 1.5. Niemelä $1716(\mathrm{H})$.

are characteristic of the old and protected pine forests in northern Finland where Postia lateritia is one of the basic elements of the wood-inhabiting fungal flora. Although the species clearly favours dry pine forests, most of the collections derive from localities which are intermixed with spruce and where the microclimatic conditions are fairly stable. Of my collections from eastern Finnish Lapland $(n=18), 78$ per cent are from forests of the Empetrum-Myrtillus site type (see Renvall et al. 1991a), and the rest were collected in the drier Uliginosum-Vaccinium-Empetrum type.

Postia lateritia has a strong annual variation in the basidiocarp production and it is difficult to estimate its actual abundance and sometimes even to verify its presence. This was clearly noted during the periods of intensive field work in 1987-1991 in eastern Finnish Lapland. The species was found only once in 1991, while in 1988, when there was an exceptionally good growing season for fungi, it was found 14 times.

\section{Postia fragilis (Fr.) Jül.}

- Figs. 3, 5

Postia fragilis (Fr.) Jül., Persoonia 11:423, 1982. Polyporus fragilis Fr., Elench. Fung.: 86, 1828. - Neotype: Sweden. Småland: Femsjö, Prästgårdsskogen, decayed stump of Pinus sylvestris, 2.X. 1940 Seth Lundell 4112a (UPS!, here selected).

Daedalea sistotremoides Velen., Mykologia (Praha) 3:102, 1926. - Lectotype: Czechoslovakia. Cechy (Bohemia): Řičany, 1922 Zverinová (PRC!) I agree with Pilát (1936) and Kotlaba (1975) that the specimen belongs to Postia fragilis.

Polyporus kavinae Velen., České houby 4-5:648, 1922. Lectotype: Czechoslovakia. Čechy (Bohemia): Struharov, 1916 Velenovsky (PRC!). As already reported by Pilát (1936) and confirmed by Kotlaba (1975) this is a synonym of Postia fragilis. 
Polyporus orbicularis Velen., České houby 4-5:687, 1922. - Lectotype: Czechoslovakia. Čechy: Šumava, 1898 Velenovský (PRC!). A synonym of Postia fragilis (see also Kotlaba 1975).

Spongipellis sensibilis Murr., Mycologia 4:93, 1912. - Holotype: U.S.A. Washington: Seattle, 1911 Murrill (NY!). When describing this taxon Murrill (1912) reported that the spores are ovoid and $5 \times 3 \mu \mathrm{m}$ in size. However, in the type spores are phaseoliform to slightly curved and cylindrical, measuring ca. 4-5 x 1.6-1.8 $\mu \mathrm{m}$. Although the pores are smaller (up to 6 per $\mathrm{mm}$ ) than in the European material, I agree with Overholts (1953) and Ryvarden (1985) that this belongs to Postia fragilis.

Basidiocarps annual, pileate or effused-reflexed, usually fairly small $(2-5 \mathrm{~cm}$ wide) but variable in size and form, mostly solitary, fairly soft and cheese-like but flexible when fresh, turning rigid and brittle on drying; resupinate areas usually small, but sometimes up to $4 \times 7 \mathrm{~cm}$ wide. Pilei sessile or dimidiate with margin sharp and often incurved after drying, up to $8 \mathrm{~cm}$ wide, projecting $0.5-5 \mathrm{~cm}$ from substrate, $0.5-2(-3) \mathrm{cm}$ thick at the base. Upper surface at first pubescent, azonate, white to buff, with age more ferruginous, glabrous, wrinkled and rugulous; when bruised turning rapidly butter yellow and after a few minutes rusty brown, and finally dirty ferruginous to dark brown. Pore surface when young and fresh white to cream and soft, when bruised turning rapidly butter yellow and then deep ferruginous, becoming widely discoloured to dirty or dark brown with age and when dry, fairly rigid but fragile; pores angular to sinuous, $2-4(-5)$ per $\mathrm{mm}$, walls thin when dry, ca. 0.04-0.1 mm thick; tube mouths somewhat lacerate to distinctly dentate, in old basidiocarps often split in flat spines, under lens $(50 \mathrm{x})$ in young, intact basidiocarps finely pubescent, in old basidiocarps and in bruised parts glabrous. Section: Context white and soft, when dry fragile and with a distinct reddishbrown to greyish tint, 3-20 mm thick. Tubes first cream but turning brownish with age, on bruising and on drying, darker than the context, up to $10 \mathrm{~mm}$ long.

Microscopy: Hyphal system monomitic, all septa with clamp connections. Context: Generative hyphae hyaline, inamyloid, indextrinoid, acyanophilous and metachromatic, thin- to somewhat thick-walled, branched and with frequent cross-walls, (2.7-)2.9-6.1(-7.1) $\mu \mathrm{m}$ wide $(\mathrm{n}=240 / 11)$, among them up to $12.8 \mu \mathrm{m}$ wide, refractive sclerified generative hyphae, most of the hyphae parallelly arranged in radial strands 5-80 $\mu \mathrm{m}$ in diam, among them loosely interwoven single hyphae and especially in the lower context plenty of winding oleiferous hyphae, no distinct basal layer. Hyphae of pileal hairs and striae mostly thin-walled, with indistinct yellowish to brownish pigmentation and with oily contents, tightly agglutinated in bundles which arise solitarily from the context, making the upper surface of the pilei pubescent to rugulous. Tubes: Tramal hyphae subparallel and fairly straight, thin-walled or more often somewhat thick-walled, (2-)2.3-4.2(-5) $\mu \mathrm{m}$ wide $(\mathrm{n}=$ $216 / 11$ ), otherwise as in context, among them gloeoplerous hyphae. Subhymenium indistinct. Hyphal pegs abundant. Basidia slender-based, clavate, with a basal clamp and four sterigmata, (14-)15-18(-19) $x$ (3.5-)4-5(-5.5) $\mu \mathrm{m}(\mathrm{n}=75 / 8)$. Basidioles slightly shorter, similar in shape. Cystidia lacking, but hyphoid cystidioles (basidiole-sized) sometimes present. Basidiospores phaseoliform to broadly allantoid, thin-walled, smooth, hyaline, inamyloid, indextrinoid and acyanophilous, (3.7-)3.9-5(-5.5) $\times(1.5-)$ $1.7-2.1(-2.3) \mu \mathrm{m}, \mathrm{L}=4.40, \mathrm{~W}=1.89, \mathrm{Q}=2.10-2.54$ $(n=303 / 10)$.

\section{Specimens examined}

Czechoslovakia. See the types.

Finland. Varsinais-Suomi: Houtskär, 1980 Alava 19348 (TUR). Kaarina, 1944 Kari (TUR). Karjaa, 1860 Hisinger (2 ex. H). Karjalohja, 1937 Laurila (2 ex. H, TUR), 1946 Malmström (H), 1980 Kotiranta 2103 et al. (H.K.). Korppoo, 1941 Eklund $(\mathrm{H}), 1972$ Niemelä (H). Kustavi, 1979 Alava 18892 (TUR). Lohja, 1947 Schulmann (2 ex. H). Turku, 1979 Alava 18862, 18865 (TUR). Vahto, 1937 Kari (2 ex. TUR). Uusimaa: Elimäki, 1948 Schulmann (H), 1971 Niemelä $(H)$. Espoo, 1974 Nordström 473 (H). Helsinki, many specimens 1936-1991 (H, HFR). Kauniainen, 1938 Nyberg $(H), 1943$ Nyberg $(H), 1980$ Venäläinen (H). Nurmijärvi, 1977, 1989 Askola (2 ex.H, T.N.). Porvoo, 1933-1935 Nyberg (5 ex. H). Porvoo rural commune, 1934-1939 Nyberg (3 ex. H). Sipoo, 1982-1988 Saarenoksa 33582 (H), 25088 (TUR), 1991 Niemelä 5503 (T.N.). Tammisaari, 1957 Schulmann $(\mathrm{H})$. Tuusula, many specimens 1940-1963 (H, HFR). Vantaa, 1987 Saarenoksa 40287 (KUO). Etelä-Karjala: Miehikkälä, 1977 Fagerström (2 ex. H). Sippola, 1977 Fagerström (H). Vehkalahti, 1960 Tiensuu (H), 1980 Fagerström (H). Satakunta: Ikaalinen, 1986 Penttilä 145, 209, 393 (H). Jämijärvi, 1940 Laurila (H). Kankaanpää, 1940 Laurila $563(\mathrm{H})$. Noormarkku, 1940 Laurila $576(\mathrm{H})$. Siikainen, 1936 Laurila $(\mathrm{H}), 1940$ Laurila $565(\mathrm{H})$. Viljakkala, 1969 Niemelä (H), 1988 Niemelä 4558 (H). Etelä-Häme: Asikkala, 1980-1984 Haikonen 711, 1653, 4915 (H). Hartola, 1983 Haikonen 3964 (H). Hattula, 1989 Renvall 1998 (P.R.). Hollola, 1981-1984 Haikonen 1705, 3186, $4813(\mathrm{H})$. Janakkala, 1970 Uotila 6712 (H), 1974 Koponen (H), 1981 Niemelä 2315, $2316(\mathrm{H})$. Jämsä, 1938 Koskinen ( 2 ex. H, 2 ex. TUR), 1967 Eurola (OULU), 1979 Kotiranta 1516, 1556, 1585 (H). Korpilahti, 1978-1979 Kotiranta 305 (H.K.), 1651 (H.K., T.N.). Kuru, 1987 Penttilä 678 (H). Lahti, 1985 Haikonen 6642 (H). Lammi, 1984 Harmaja et al. (T.N.). Lempäälä, 1860 Karsten 3490 (H), 1983 Söderholm $1045(\mathrm{H})$. Luhanka, 1989 Kotiranta $7866(\mathrm{H})$. Nastola, 1984 Haikonen $4885(\mathrm{H})$. Padasjoki, 1979-1980 Kotiranta 1728, 2568 (H), 2477 (H.K.), 1991 Renvall 2665, 2666 (H). Somero, 1967 Såltin (TUR), 1968 unnamed (HFR 022014). Tammela, 1862-1892 Karsten 1797a, 3481-3486 (H), 1967 Koivisto (TUR), 1980 Niemelä 2044 (H). Tampere, 1975 Söderholm (H). Etelä-Savo: Punkaharju, 1972 unnamed (HFR 022101, 022088), 


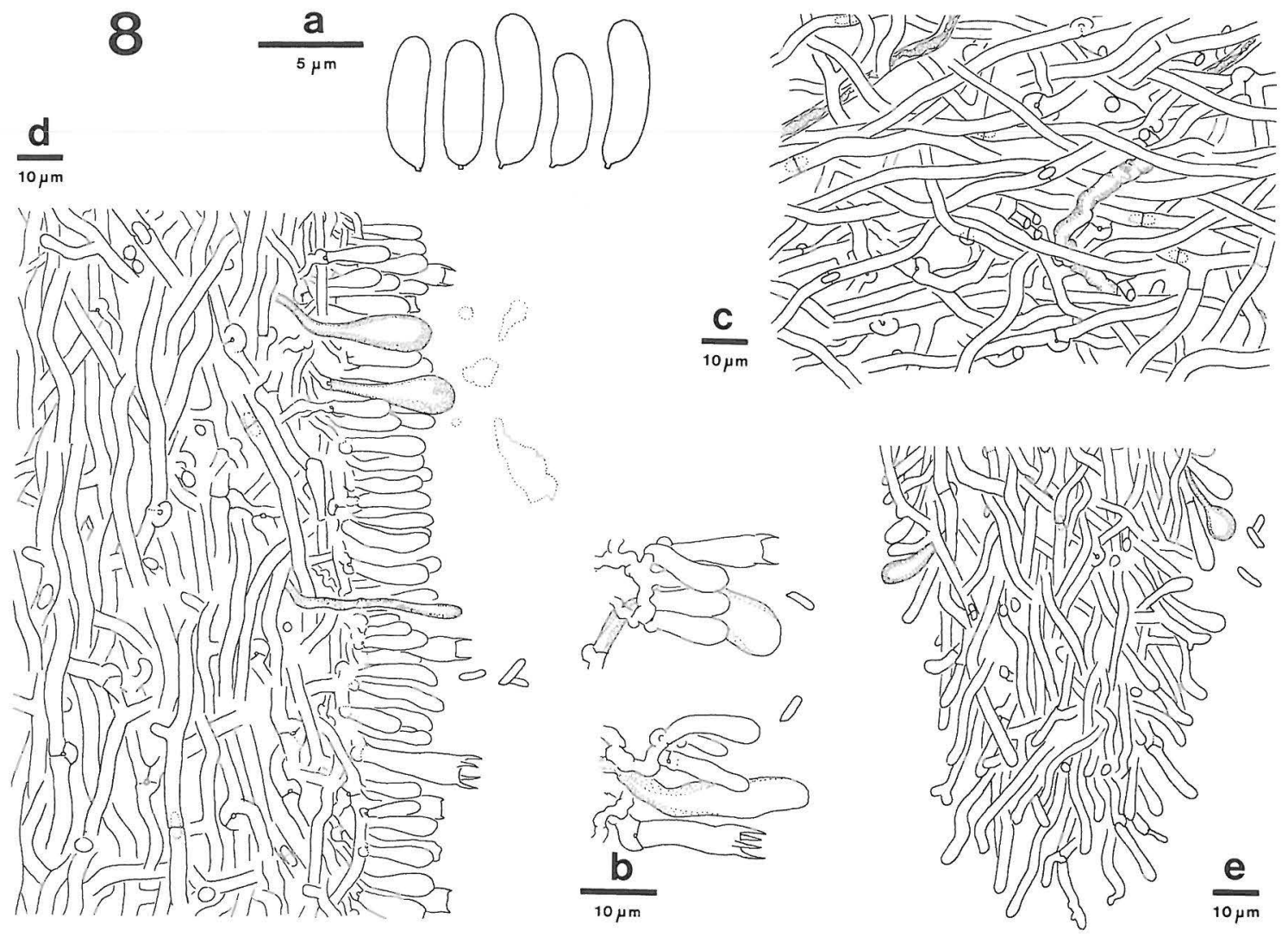

Fig. ४. Anatomical details of Postia leucomallella (Murr.) Jül.: a) basidiospores, b) basidia, basidioles and gloeocystidia, c) a section through middle context showing branched generative hyphae and a gloeoplerous hypha, d) a vertical section through upper dissepiment, e) dissepiment edge in a vertical section. Drawn in Cotton Blue. From the holotype of Tyromyces gloeocystidiatus Kotl. \& Pouz. (PRM 203596).

1987 Kotiranta $6555(\mathrm{H})$. Valkeala, 1977 Fagerström (H). Pohjois-Häme: Ähtäri, 1970 Pohjola \& Ulvinen (OULU). PohjoisSavo: Kuopio, 1967 Hakala (2 ex. KUO). Vieremä, 1970 Puustinen $(\mathrm{H})$, Penttilä $1534(\mathrm{H})$. Pohjois-Karjala: Kitee, 1980 Niemelä 2014 (T.N.). Lieksa, 1989 Penttilä 1216, 1225 (H). Pielisjärvi, 1936 Laurila (TUR), 1956 Kujala A2401 (H). Tuupovaara, 1967 Takala 4597 (OULU). Keski-Pohjanmaa: Haapavesi, 1970 Koskela (OULU). Kainuu: Kuhmo, 1990-1991 Penttilă 1616, 1631, $2494(\mathrm{H})$. Oulun Pohjanmaa: Haukipudas, 1979 UIvinen (OULU), 1981-1988 Ohenoja (3 ex. OULU). Muhos, 1965 Eurola (OULU), 1982 Heikkinen (OULU). Oulu, 1974 Saaristo (OULU), Ulvinen (3 ex. OULU). Inarin Lappi: Inari, 1989 Kotiranta $7694(\mathrm{H})$.

Sine loco: 'Ölstens', 1938 Nyberg $(\mathrm{H})$.

France. 'Gallia austr. - orient' ? Quélet (UPS).

Russia. Leningrad Region: Vyborg, 1892 Thesleff (3 ex. H). Karelia: Vichka River, 1942 Laurila $564(\mathrm{H})$.

Sweden. Smalland: see the type. Uppland: Alsike, 1856 E.P. Fries (UPS). Börje, 1943-1948 Lundell (F. Exs. Suecici 2618, UPS).Vaksala, 1941 Fåhraeus 18305 (UPS). Lule Lappmark: Gällivare, 1947 Eriksson 2111 (UPS).
U.S.A. New York: Warrensburg, 1949 Lowe $3782(\mathrm{H})$. Washington: see the types.

Postia leucomallella (Murr.) Jül. — Figs. 7, 8

Postia leucomallella (Murr.) Jül., Persoonia 11:423, 1982. Tyromyces leucomallellus Murr., Bull. Torrey Bot. Club 67:63, 1940. - Type: U.S.A. Florida: Newman's Lake, 1938 Murrill (FLAS 18231!).

Polyporus separabilis Velenovský ex Pilát, Atlas Champ. Eur. 3(34-35):176, 1937 (nomen nudum). I have studied two original specimens of Velenovský which both belong to Postia leucomallella. Kotlaba (1975) reports that both in PRC and PRM there is also a specimen of $P$. lactea (Fr.) Karst. under this name.

Tyromyces gloeocystidiatus Kotl. \& Pouz., Cèská Mykol. 18:207, 1964. - Holotype: Czechoslovakia. Cechy (Bohemia): Benešov nad Cernou, 1963 Kotlaba \& Pouzar (PRM 203596!). In the type basidiospores measure 4.7-6.1 x 1.3-1.8 $\mu \mathrm{m}(\mathrm{n}=30)$, 
being somewhat shorter than those in the type of $T$. leucomallellus $(5-6.8 \times 1.3-1.8 \mu \mathrm{m}, \mathrm{n}=30)$. In other features (gloeocystidia, gloeoplerous hyphae, hyphal system) these two are very similar, and, although the type of $T$. leucomallellus is in a rather poor condition, I keep these two as a single species. This has already been proposed, e.g., by Lowe (1975) and Ryvarden (1978).

Basidiocarps annual, pileate, effused-reflexed, with an elongated pileus bordering the upper edge of the tube layer, or resupinate, variable in size, solitary or more often gregarious with several pilei, soft cheese-like when fresh, rigid and chalky brittle when dry, splitting easily along the tubes in both fresh and dry condition; resupinate areas usually $1-3 \times 3-10 \mathrm{~cm}$ in size, but sometimes up to one meter wide along a fallen trunk. Pilei broadly attached, often confluent, with a slightly incurved and fairly sharp or blunt margin, up to $9 \mathrm{~cm}$ wide, projecting $0.3-3 \mathrm{~cm}$ from substrate, $0.5-3.5 \mathrm{~cm}$ thick at the base. Upper surface azonate or with an uneven and brownish zone near the pileal margin, when fresh and young finely fibrillose, white to cream with ferruginous irregular dots, with age smooth, becoming more dirty brownish and when dry often somewhat scrupose and wrinkled, when bruised turning very slowly greyish brown without a yellow phase. Pore surface when young and fresh white to cream and soft, turning very slowly dirty brown or greyish in strongly-bruised parts, becoming yellowish to dirty brown and fragile with age and when dry; pores angular to sinuous, (2-)3-4(-5) per $\mathrm{mm}$, walls thin, ca. $0.03-0.07 \mathrm{~mm}$ thick when dry; tube mouths even to distinctly lacerate when dry, under lens $(50 \mathrm{x})$ in young, unbruised basidiocarps finely pubescent, in old basidiocarps and in bruised parts glabrous. Section: Context white and soft, when dry brittle and chalky. Tubes first soft and cream but turning soon wood-coloured to brownish, rigid and brittle when dry, darker than the context, up to $10 \mathrm{~mm}$ long.

Microscopy: Hyphal system monomitic, all septa with clamp connections. Context: Hyphae hyaline, inamyloid, indextrinoid, acyanophilous and metachromatic, mostly thin-walled, richly branched and with frequent cross-walls, (2.2-)2.8-5(-6.5) $\mu \mathrm{m}$ wide ( $n=204 / 10$ ), fairly loosely arranged, with age more densely packed, without a distinct basal layer, a few hyphae gloeoplerous. Hyphae in the pileal surface thin-walled and in young basidiocarps arranged in strands or arising separately from the context, with age more agglutinated and usually somewhat gelatinized, without distinct pigmentation.Tubes: tramal hyphae with a greyish tint in IKI, subparallel and fairly straight, thin- to fairly thick-walled, (1.8-)2.1-3.8(-4) $\mu \mathrm{m}$ wide $(\mathrm{n}=200 / 10)$, with frequent and short side branches, when dry fragile and easily broken, at dissepiment edges straight to undulating and somewhat interwoven, otherwise as in context, a few hyphae gloeoplerous. Subhymenium indistinct. Hyphal pegs abundant. Basidia slender-based, clavate, with a basal clamp and four sterigmata, (13-)15-18.5(-19) x (3.5-)4-5(-6) $\mu \mathrm{m}(\mathrm{n}=91 / 9)$. Basidioles slightly shorter, similar in shape. Gloeocystidia always present, usually (especially in old basidiocarps) abundant, cylindrical to pyriform, thinwalled, yellow in IKI and deep yellowish blue in $\mathrm{CB}$, with oily contents, variable in size, $19-42(-68) \times$ $4-9(-9.5)(n=45 / 10)$, often rooting deep from the subhymenium, usually somewhat projecting above the hymenial surface. Basidiospores slightly curved and narrowly cylindrical to allantoid, thin-walled, smooth, hyaline, inamyloid, indextrinoid and acyanophilous, (4.3-)4.6-6.3(-7) $\times 1.3-1.8 \mu \mathrm{m}$, $\mathrm{L}=5.28, \mathrm{~W}=1.53, \mathrm{Q}=3.20-3.91(\mathrm{n}=306 / 10)$.

\section{Specimens examined}

Austria. Niederösterreich: Gutenstein, 1982 Niemelä 2822 (T.N.).

Belgium. Namur: Fronville, 1969 Demoulin (H).

Czechoslovakia. Čechy (Bohemia): Jirny, 1922 Velenovský (as Polyporus separabilis Velen., PRC, PRM 33602). Soběslav, 1973 Kotlaba et al. (H).

Finland. Ahvenanmaa: Vårdö, 1967 Olofsson (H). Varsinais-Suomi: Kisko, 1988 Renvall $1449(\mathrm{H})$. Kustavi, 1979-1981 Alava 19061, 19930 (TUR). Nousiainen, 1983 Kotiranta 5187 (H). Parainen, 1967-1972 Niemelä (2 ex. T.N.), 1980 Alava 19408 (TUR), 1988 Heinonen 154-88 (TUR). Raisio, 1936 Auer (TUR), 19?? Laurila, Auer \& Kari (H). Uusimaa: Helsinki, 1985-1988 Saarenoksa 32185, 08688, $44488(\mathrm{H}), 36188$ (KUO), 36288 (OULU, TUR), 36388 (TUR), 36588 (KUO), 45388 (KUO). Kirkkonummi, 1963 Kujala B3225 (HFR), 1970 Niemelä (H, T.N.). Mäntsälä, 1985 Haikonen 6707 (H). Riihimäki, 1962 Schulmann (H). Ruotsinpyhtää, 1979 Kotiranta (H.K.). Sipoo, 1981 Niemelä 2334 (T.N.), 1986 Saarenoksa 36686 (H, H.K., KUO, OULU, TUR), 1987 Saarenoksa 39687 (H). Tuusula, 1966 Laine (HFR 022266). Vantaa, 1987 Saarenoksa $40387(\mathrm{H})$. Etelä-Karjala: Vehkalahti, 1966 Laine \& Kurkela (H, 2 ex. HFR), 1979-1980 Fagerström (3 ex. H, T.N.). Virolahti, 1989 Hietala (H.K.). Satakunta: Ikaalinen, 1986 Penttilä $155(\mathrm{H})$. Kankaanpää, 1936 Laurila (2 ex. H). Kullaa, 1938 Laurila 579 (H). Etelä-Häme: Asikkala, 1981-1991 Haikonen 1862, $13529(\mathrm{H})$. Heinola, 1983 Haikonen $3958(\mathrm{H})$. Heinola rural commune, 1985 Haikonen $6391(H)$. Jämsänkoski, 1967 Koskinen (H). Kuru, 1986-1987 Penttilä 242, $830(\mathrm{H})$. Kärkölä, 1981 Haikonen 1486 (H). Lammi, 1979-1983 Niemelä 1716, 1722, 2324 (T.N.), 2939 (H), 1981-1984 Kotiranta 2737 (H.K.), 5937 (H). Padasjoki, 1976 Niemelä (T.N.), 1979-1981 Kotiranta 1719, 1734, 2885, 2900 (H), 1733 (H, H.K.), 1860 (T.N.), 1985 Niemelä 3306 (H). Pertunmaa, 1985 Haikonen $6508(\mathrm{H})$. Tammela, 1866-1886 Karsten 1719b, 2248c, 3487 (H), 1882-1888 O. Karsten (4 ex. H), 1980 Niemelä 2040 (T.N.). Etelä-Savo: Hirvensalmi, 1987 Rosenlew (H). Ruokolahti, 1979 Haikonen $281(\mathrm{H})$. Savitaipale, 1967 Niemelä et al. (H). Valkeala, 1977 Fagerström (H). Pohjois-Häme: Saarijärvi, 1981 Kotiranta 2940 (H.K.), 1984-1987 Kotiranta 5424, 5984, 


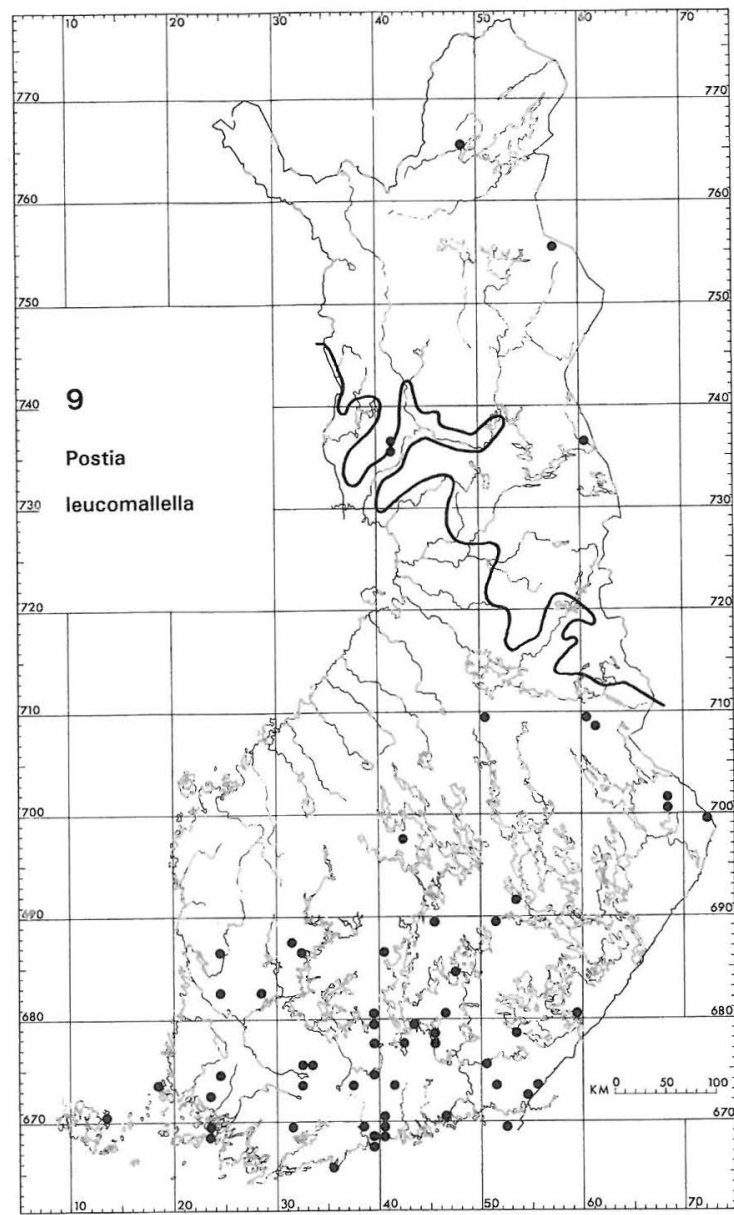

Fig. 9. The distribution of Postia leucomallella (Murr.) Jül. in Finland according to the material examined. The black line indicates the southern border of the Northern Boreal vegetation zone (according to Ahti et al. 1968).

6000 (H). Toivakka, 1989 Ohenoja (OULU). Pohjois-Savo: Jäppilä, 1987 Haikonen $8931(\mathrm{H})$. Vieremä, 1989 Penttilä 1463, $1574(\mathrm{H})$. Virtasalmi, 1985 Haikonen $6592(\mathrm{H})$. Pohjois-Karjala: Ilomantsi, 1985 Söderholm $1179(\mathrm{H})$. Lieksa, 1988-1990 Penttilä 1034, 1289b, 1933, 1939, 1963 (H). Kainuu: Kuhmo, 1990 Penttilä 1592, 1694, 1717 (H). Perä-Pohjanmaa: Rovaniemi rural commune, 1979-1980 Niemelä 1511, 1521, $2081(\mathrm{H})$, 1981 Kotiranta $7833(\mathrm{H})$. Tervola, 1980-1989 Kotiranta 2182, 7099 (H), 7806 (H, H.K.). Koillismaa: Kuusamo, 1988 Kotiranta $7082(\mathrm{H})$. Sompion Lappi: Savukoski, 1988 Renvall 1370 (H). Inarin Lappi: Inari, 1981 Kotiranta $3055(\mathrm{H})$.

Germany. Westfalen: Detmold-Hiddesen, 1976 Jahn (T.N.). Sine loco: 'Lorschausener Wald am Rhein', 1938 Sponheimer (UPS, ex PRM 491015).
Norway. Hordaland: Birkeland, 1951 Eriksson 5871, 5853 (UPS). Buskerud: Nes, 1951 Stordal 7026 (GB-J.E. 3720).

Poland: Woj. krakowskie: Ojców Nat. Park, 1978 Niemelä $1356(\mathrm{H})$.

Russia. Leningrad Region: Vyborg, 1892 Thesleff (2 ex., H). Karelia: Sel'ghi (Selki), 1943 Kari (TUR). Vedlozero (Vieljärvi), 1943 Railonsala (TUR). Vichka River, 1942 Laurila (H).

Sweden. Skåne: Torekov, 1946 Eriksson 1043 (UPS). Halland: Östra Karup, 1945 Foghammar (UPS), 1949 Eriksson 3928 (UPS). Småland: Femsjö, 1939-1943 Lundell 1565, 1645, 4126, 4127 (UPS). Gotland: Visby, 1945 E.Th. Fries (UPS). Göteborgs-omrddet: Göteborg, 1954 Karlvall 6296 (UPS), 1955 Karlvall (F. Exs. Suecici 2619, as Polyporus lowei, UPS). Västra Frölunda, 1969 Nordin 4868 (UPS). Uppland: Bondkyrka, 1931 Lundell 1324 (UPS). Vänge, 1973 Ryman 1092 (UPS). Hälsingland: Harmånger, 1944 Eriksson 219 (UPS), 1945 Eriksson 393 , 441 (UPS)

U.S.A. See the type.

Kotiranta and Niemelä (1981) published a map on the Finnish distribution of Postia leucomallella but that material included some specimens of $P$. lateritia and lacks the records of the last ten years. For these reasons a revised map (Fig. 9) is presented here.

\section{Discussion}

The fact that Postia lateritia has escaped the attention of mycologists for so long must be due to its similarities with its ferruginous relatives, particularly $P$. fragilis. The both species attain rust-tinted flecks when touched or bruised and, on the other hand, they both lack cystidia or other specific details. A species with a striking key character (e.g., exceptionally large pores, striking colour change, gloeocystidia) may, as beautifully shown by Niemelä and Penttilä (1992), mask another related taxon because of that single and easily observable character. Those look-alikes tend to remain unobserved if accurate microscopical examinations and ecological notes are omitted.

Postia lateritia differs from $P$. leucomallella and $P$. fragilis by its soft, easily collapsing and small pilei with variably brick-red and floccose upper surface (Figs. 2, 3, 7). Although the basidiocarps of $P$. leucomallella and $P$. fragilis vary greatly in their size and form, they are generally more sturdy and the upper surface becomes with age more rugulose, harder, and the brown colour is dark and dull, not bright reddish. There is no rapid colour change in $P$. leucomallella, while the bruised parts of $P$. fragilis turn almost instantly butter yellow and then deep ferruginous and the colours deepen on drying. In $P$. lateritia the final colour is more or less similar but the quick phase of butter yellow may totally lack. In addition, in $P$. lateritia the ferruginous parts are distinctly predominated by reddish colours and the unbruised pore surface remains white. The contrast 


\section{Spore width $\mu \mathrm{m}$}

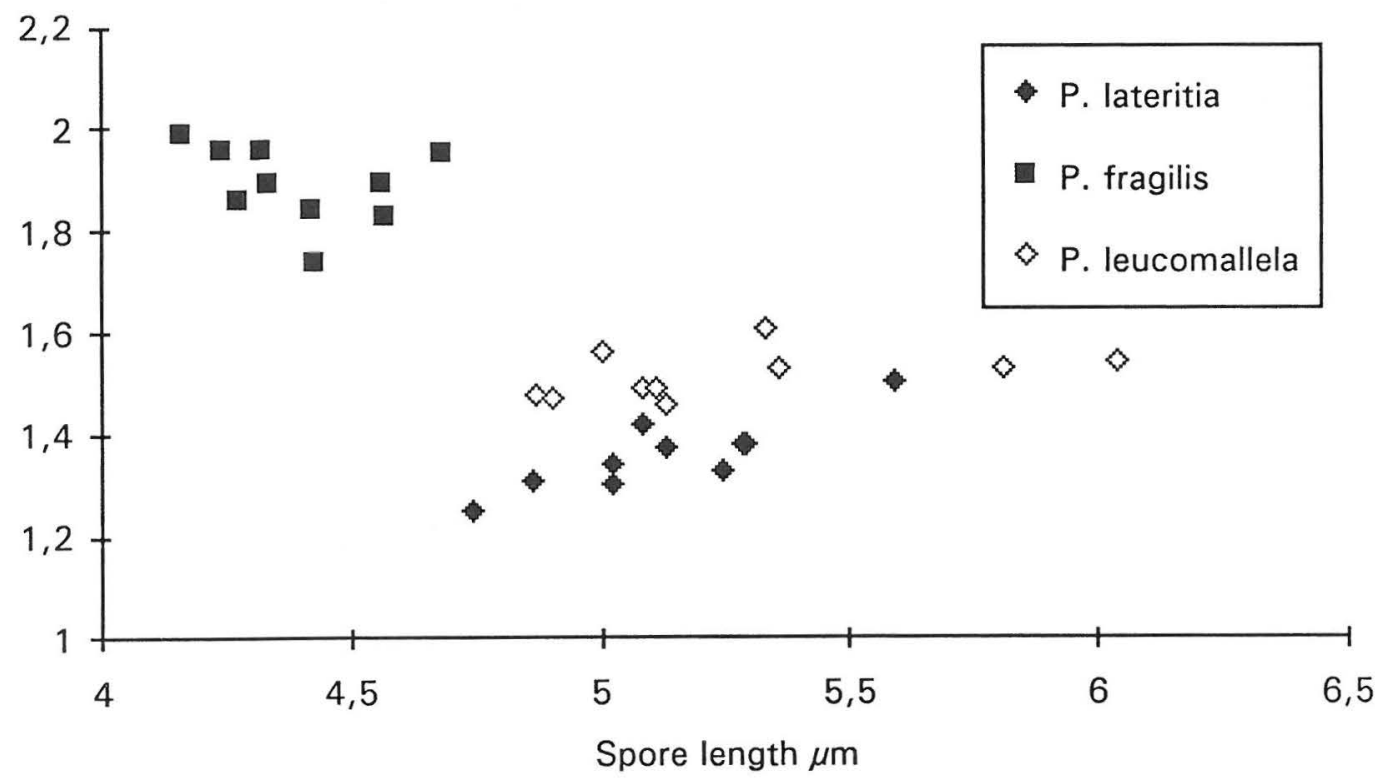

Fig. 10. The variation of the mean spore size in the ten selected specimens of Postia lateritia Renvall, P. fragilis (Fr.) Jül. and $P$. leucomallella (Murr.) Jül. (30-40 measurements of spores per specimen).

between the bright tomentum and white pores is usually the first aid of identification both in herbarium and in the field.

Dry specimens are also determinable by their general habit. $P$. lateritia keeps its softness after drying, while both $P$. fragilis and $P$. leucomallella turn more or less hard and fragile. The basidiocarps of $P$. fragilis mostly turn brittle-hard on their surface, but are fragile inside, which is due to the arrangement of contextual hyphae. The outer structure of $P$. leucomallella is fairly compact, but the context is fragile to almost chalky and the tubes dry rigid and very brittle.

Although resembling macroscopically each other, the three species are easily identified in the microscope. Gloeocystidia (pseudocystidia or macrocystidia according to Largent et al. 1977) are always present in Postia leucomallella and especially in old basidiocarps they are abundant (Figs. 8b, d, e).P. leucomallella is also characterized by its thin-walled and subparallel tramal generative hyphae with fairly abundant and characteristically short side branches and richly branched contextual hyphae (Figs. 8c, d).
Both $P$. fragilis and $P$. lateritia lack cystidia and have rarely branched and somewhat thick-walled hyphae. They can be identified from each other by basidiospore and hyphal characters. $P$. lateritia has allantoid and fairly narrow spores (narrower than $1.6 \mu \mathrm{m}$ ), while the spores of $P$. fragilis are more or less phaseoliform and fairly thick (thicker than $1.7 \mu \mathrm{m}$; Fig. 10). The hymenial cells are longer in $P$. lateritia than in $P$. fragilis. The contextual hyphae of $P$. fragilis are thicker than in $P$. lateritia and they are characteristically arranged in radial hyphal strands (Figs. 5c, e, f) which arise from the context and make the upper surface of the pileus pubescent to rugulous. In addition, the hyphae in the pileal surface are mostly thin-walled and lack the distinct pigmentation. In $P$. lateritia the contextual hyphae are spaced, interwoven and without any orientation (Fig. 1d). The hyphae in ferruginous parts of the pileal surface are distinctly thick-walled and have a characteristic reddish brown pigmentation (Fig. 1e). Moreover, the tomentum is made up of single hyphae which arise from the loose context, and the result is the soft floccose appearance of the upper surface. 
Postia lateritia can be distinguished also by its ecological features. In Finland it is restricted to pine, while $P$. fragilis and $P$. leucomallella inhabit spruce in fairly moist habitats as well (Table 1). This indicates a different adaptation to the moisture and perhaps a need of different fungal associates. The species are separable also by their climatic requirements. $P$. lateritia evidently occurs throughout the Boreal zone, although it seems to prefer more continental Northern Boreal forests (Fig. 4). In Finland both $P$. fragilis and $P$. leucomallella are fairly strictly restricted to the Southern and Middle Boreal zone, and only a few finds derive from the Northen Boreal parts of the country (Figs. 6, 9), although many suitable forests have been thoroughly checked.

Postia undosa (Peck) Jül. and P. leucospongia are reminiscent of $P$. lateritia in microscope, but macroscopically their identification is easy. $P$. undosa (NYS!) has characteristically undulating and flexible pilei with large and sinuous pores $(1-3 / \mathrm{mm})$, and thick-walled generative hyphae and partly gelatinized trama make the species identifiable in the microscope. $P$. leucospongia is characterized by its fairly large basidiocarps with spongy and very soft upper surface. Like $P$. lateritia, also that species is very soft and, although the tubes turn fragile, the context keeps its softness after drying. $P$. hibernica (Berk. \& Br.) Jül. which inhabits same habitats as $P$. lateritia can be identified by its white to cream basidiocarps which totally lack the ferruginous colours

Table 1. Host range (in per cent) of the three ferruginous polypore species of Postia Fr. in Finland according to the herbarium material examined ( $\mathrm{n}=$ total number of specimens).

\begin{tabular}{lrcc}
\hline Host & P. fragilis & P. lateritia & $\begin{array}{c}\text { P. leuco- } \\
\text { mallella }\end{array}$ \\
\hline Picea abies & 36 & - & 25 \\
Pinus sylvestris & 37 & 97 & 68 \\
$P$. cembra & 1 & - & - \\
P.peuce & 1 & - & - \\
Coniferous tree sp. & 8 & 3 & 7 \\
Alnus incana & 1 & - & - \\
Unidentified host & 16 & - & - \\
$\mathrm{n}$ & 139 & 87 & 123 \\
\hline
\end{tabular}

and in microscope by its longer and more cylindrical basidiospores and projecting cystidia.

Other ferruginous polypores may also resemble the species of the Postia fragilis group, but usually they are easily identifiable in the microscope. Amylocystis lapponica (Rom.) Singer is characterized by strongly amyloid cystidia and hyphae. Parmastomyces mollissimus (R. Maire) Pouzar ( $P$. transmutans (Overh.) Ryv. \& Gilb.) (see Pouzar 1984) is easy to identify by its dextrinoid and strongly cyanophilous, fairly thick (2.5-4 $\mu \mathrm{m}$ according to Gilbertson \& Ryvarden 1987) basidiospores. Aurantioporus alborubescens (Bourdot \& Galzin) H. Jahn has resinous tubes, larger (5-8 $\times 4-5 \mu \mathrm{m})$ basidiospores and it is known to grow only on broad-leaved trees, mostly Fagus sylvatica L. (see Koch 1975).

\section{Excluded taxa}

Leptoporus lowei Pilát

Sborn. Nár. Mus. Praha 9B:101, 1953. (lectotype, PRM 487991!).

Not Postia lateritia. See the section on the identity of Oligoporus lowei.

\section{Polyporus keithii Berk. \& Br.}

Ann. Mag. Nat. Hist. (Ser. 4) 15:30, 1875.

I have not had an opportunity to study the type specimen (K), but according to Reid and Austwick (1963) it could be interpreted as Postia fragilis (as Polyporus mollis Fr.). They reported that the context is characterized by highly refractive, conducting elements 5-11 $\mu \mathrm{m}$ in diam, which fits Postia fragilis.

\section{Polyporus vermiculus Veull.}

in Roumeguère, Rev. Mycol. 5:46, 1883.

According to Jülich (1984) this is a synonym of Postia fragilis.

\section{Polyporus weinmannii Fr.}

Epicrisis Syst. Myc.: 459, 1838.

No authentic material is available of this species, although Donk (1974) concluded that there may be an isotype at $\mathrm{K}$. This has traditionally been treated as a synonym of Postia fragilis (see Donk 1974).

\section{Tyromyces newellianus Murr.}

Bull. Torrey Bot. Club 67:64, 1940 (holotype, F 18215!).

Lowe (1975) and Ryvarden (1978) have proposed that this is a synonym of Postia leucomallella. The 
species are macroscopically very similar and also the type of Tyromyces newellianus has abundant gloeocystidia (a rare character among polypores) and monomitic hyphal system. However, basidiospores and basidia are in the type of $T$. newellianus distinctly shorter than in Postia leucomallella, measuring 4.1-5 $\times 1.2-1.5 \mu \mathrm{m}, \mathrm{L}=4.47, \mathrm{~W}=1.38, \mathrm{Q}=3.23(\mathrm{n}=40)$, $8-13 \times 3.5-4 \mu \mathrm{m}(\mathrm{n}=30)$, respectively. $P$. leucomallella is known to grow only on conifers (Ryvarden 1978, Gilbertson \& Ryvarden 1987), while the type specimen of Tyromyces newellianus was collected from a 'hardwood log'. For these reasons I am not convinced that $T$. newellianus and Postia leucomallella represent the same species. Although Lowe (1975) treated these as a single species, also he had doubts about the taxon: in 1970 he left a note 'Spores are shorter than usual, may be another species' into the type of Tyromyces newellianus. On the other hand, on examination of the type material alone, I hesitate to make any definite conclusion.

\section{Nomenclatural status of Postia Fr.}

Mycologists have for ten years discussed on what is the correct generic name for the brown-rot-causing polypores which have a monomitic hyphal system and clamped generative hyphae. The dispute culminates on the interpretation and validity of the name Postia Fr. The discussion arose after David's (1980) innovative revision of the genus Tyromyces $\mathrm{s}$. lat. She divided the group into smaller genera and chose the name Spongiporus Murr. to comprise the species defined above. Her generic concept has been widely accepted, but older generic names were found to substitute Spongiporus.

Fries (1874) introduced the genus Postia for a few polypores with soft basidiocarps and thin dissepiments. Based evidently on Donk's (1960) thorough analysis, Jülich (1982) combined 18 European species in that genus. His solution (Jülich 1982, 1984) was accepted by Larsen and Lombard (1986) in North America, who added eight new species in Postia. In Europe e.g., Breitenbach and Kränzlin (1986) and Renvall et al. (1991) have adopted the name Postia.

Suspects on the validity of the name Postia make up the major obstacle to its use. According to Teixeira (1986) it is just a nomen provisorium, while Gilbertson and Ryvarden $(1985,1987)$ rejected it as a nomen nudum. The latter (Gilbertson \& Ryvarden 1987) stated that 'Fries himself gave no indication that he intended to publish a new genus and used the name only incidentally in the middle of a sentence'. Accordingly they rejected the proposals of Jülich (1982) and Larsen and Lombard (1986) and replaced Postia by
Oligoporus Bref., which was found to be an older name for the Spongiporus of David (1980). Despite the arguments adduced by Larsen and Lombard (1986), Ryvarden (1991) concluded that Postia is a nomen provisorium and it should be rejected as an invalid name.

According to Ryvarden (1991) the purpose of Fries (1874) was merely to mention the name Postia incidentally under the descriptions of the other genera. This is not the case: When Fries introduced Postia, it was clear that he intended to describe a genus instead of providing merely a provisional name. In Hymenomycetes Europaei (pp. 522-523), he mentions his new genus Postia which, according to him, 'has to be added as a new genus beside Polyporus, Polystictus and Trametes and which I shall discuss more under Daedalea'. On page 586 he identifies his new genus by providing a description with a list of species (indicated by numbers referring to the text under Polyporus) belonging to that genus. In the description he says that 'More distant are many Polypori viz. n. 74-76, 84, 88, 110 etc. which have sinuous, labyrinthiform and intricate pores, and which differ from the real Polypori as the genus Daedalea from Trametes. They are easily distinguished from Daedalea by their soft context, thin and narrow pores, delicate dissepiments and absence of discoloured trama. Those species are most exactly distinguished as a particular genus under the name Postia.' These passages have been printed in their original wording (in Latin) by Donk (1960). Accordingly, because of the informative description, Postia is neither a nomen nudum, a nomen dubium nor a nomen provisorium.

Ryvarden (1991) considers that the special treatment of Postia in Hymenomycetes Europaei (Fries 1874) indicates that the genus was not accepted by Fries himself. However, the deviating typography (e.g., lack of Roman numerals) in the introduction of Postia can best be explained by a contradiction of a late decision vs. a laborious typesetting. It was easier to add Postia in one or two paragraphs, than to tear down the long ready-set sections. Fries had clearly made up his mind on Postia and treats it as a distinct genus. Although he did not formally present any combinations in Postia, it does not affect, as pointed out already by Larsen and Lombard (1986), validity of the genus. Postia can be interpreted as an alternative name, still being legitimate (see Greuter et al. 1988: article 34.3.). Also the typification of Postia has been fixed: Donk (1960) selected Polyporus lacteus Fr. as the type species, and his solution has been accepted by all the subsequent authors (see Ryvarden 1991). Thus, Postia is validly published and the correct generic name for the species of my study. 


\section{Delimitation of Postia Fr.}

Another and more down-to-earth question is how large entity of species should Postia be, and variable generic divisions have been proposed for the brownrot-causing polypores with a monomitic hyphal system. In order to outline more natural groups of fungi, Pouzar (1967) first described the genus Strangulidium Pouzar for Polyporus sericeomollis Romell and P. rennyi Berk. \& Br., but later (Pouzar 1984) adopted an older name Oligoporus for the purpose. His division was accepted by Domanski (1972), but Lowe (1975) kept the collective concept. Jülich (1982, 1984) has presented another arrangement and placed $P$. sericeomollis back to the large genus (under Postia) and reserved Oligoporus only for the species with an imperfect state, like $O$. rennyi and $O$.ptychogaster (Ludw.) Falck \& O. Falck. However, although the two last-mentioned species belong to a separable group, I feel it poorly grounded to separate them merely on the basis of chlamydospore production. Many other species, e.g., O. cerifluus (Berk. \& Curt.) Gilb. \& Ryv. and $O$. floriformis (Quél.) Gilb. \& Ryv. (T. Niemelä, pers. comm.) produce chlamydospores even in nature. A broader concept was brought about, when Gilbertson and Ryvarden (1985, 1987, under Oligoporus) merged 25 brown-rot-causing polypores with a monomitic hyphal system and clamped generative hyphae. This entity is easy to key out, and its wide acceptance is therefore understandable. Although the delimitation practically solves the difficulties in separating the smaller genera, it does not try to remove the problems of phylogenetic heterogeneity of the group.

In my opinion, the separation of Oligoporus from Postia is an acceptable step towards the natural classification of tyromycetoid polypores and in this respect I follow Niemelä (Erkkilä \& Niemelä 1986) who has provided an intermediary delimitation according to which the genera Postia (as Spongiporus) and Oligoporus should be separated. Although he omitted keys to the taxa, he presented a list of characters describing the species of Oligoporus. According to him the core of the genus comprises species with shortly cylindrical to broadly ellipsoid, variably thick-walled and cyanophilous basidiospores and the tendency to produce chlamydospores. Based on this he placed $O$. balsameus (Peck) Gilb. \& Ryv., $O$. cerifluus, $O$. floriformis, O. ptychogaster, O. rennyi and $O$. sericeomollis under Oligoporus. If Oligoporus in this sense is excluded, Postia becomes a homogeneous genus comprising species with allantoid to cylindrical, thin-walled and acyanophilous basidiospores, clavate basidia and even other characters in common.

\section{Note on Poria johnstonii Murr.}

According to Vampola (1991) the type of Poria johnstonii Murr. $(\mathrm{K})$ is a cream-coloured specimen of Diplomitoporus lindbladii (Berk.) Gilb. \& Ryv., and therefore he gave a new name Oligoporus septentrionalis Vampola for the very rare polypore earlier known as Postia johnstonii (Murr.) Jül. (e.g., Ryvarden 1978, Jülich 1984). The species is characterized by pale citric yellow and resupinate basidiocarps with a monomitic hyphal system and cylindrical to slightly curved, thin-walled and acyanophilous basidiospores. Because of the spore characters I am not able to place it under Oligoporus and the following new combination is therefore proposed:

Postia septentrionalis (Vampola) Renvall, n. comb.

Basionym: Oligoporus septentrionalis Vampola 1991, Česká Mykol. 45:147 (holotype PRM, not studied).

\section{Identity of Oligoporus lowei (Pilát) Gilb.\& Ryv.}

I have examined the type of Leptoporus lowei (PRM 487991) and another original collection (UPS, ex PRM 488452) from the type locality, identified by Pilát (1938) himself. This taxon has remained poorly known due to the lack of striking characters and the scantiness of its collections. The species was described and illustrated e.g., by Domański (1964, 1972) and David (1980), and I agree with them that it should be accepted as a species of its own. It resembles Postia leucomallella but lacks gloeocystidia. Basidiospores are thicker than in P. lateritia, but fairly similar to those in $P$. fragitis, measuring (4.6-) 4.8-5.2 x 1.8-2.1(-2.2) $\mu \mathrm{m}(\mathrm{n}=30)$ in the type. However, they are slightly thick-walled and weakly cyanophilous, tapering somewhat towards the apiculus. Oligoporus lowei lacks the distinct colour change and the bundle-like arrangement of agglutinated contextual hyphae which characterize Postia fragilis.

Oligoporus lowei is indeed very close to the $O$. cerifluus complex and I am inclined to place it under Oligoporus. Similarities are, e.g., the weakly cyanophilous and slightly curved, cylindrical-ellipsoid basidiospores and the mostly thick-walled, richly branched generative hyphae which swell somewhat in $\mathrm{KOH}$, like those of $O$. cerifluus. A closer study is needed to work out the proper species limits in the $O$. cerifluus group, and in that connection also other species names, such as Leptoporus minusculoides Pilát, Polyporus revolutus Bres., Tyromyces subpendulus Atk. should be reconsidered. 
In recent Finnish mycofloristic papers (Kotiranta \& Niemelä 1981, Niemelä 1991, Renvall et al. 1991b, Rassi et al. 1992) Postia lateritia has been treated as a taxon of its own, but it has been misinterpreted as Oligoporus lowei (or Postia lowei). Accordingly, the identifications of Postia lowei in the papers cited above are all referable to $P$. lateritia. Therefore I here present a correction to the occurrence of Oligoporus lowe $i$ in Finland: according to the present material the species has not been recorded from the country.

Acknowledgements. I am deeply indebted to my supervisor Dr. Tuomo Niemelä (Helsinki) for his friendly guidance and encouragement to study wood-inhabiting fungi and, in particular, this group of polypores. He was aware that the species discussed in this paper deserve a closer study and his generous help during the preparation of the manuscript was indispensable. I also thank him for the beautiful photographs of $P$. fragilis and $P$. leucomallella. He, Heikki Kotiranta, Lic.Phil. and Reijo Penttilä, M.Sc. (all from Helsinki) kindly gave specimens at my disposal. I appreciate their valuable collecting activity without which the distribution maps would not have been worth publishing. Prof. Teuvo Ahti (Helsinki) generously helped with the Latin translations and nomenclatural problems; he also translated the Latin description. I wish to thank the curators of the following herbaria for arranging loans of the type specimens and other material: F, H, HFR, JOE, KUO, NY, OULU, PRC, PRM, TUR. Dr. Sharon P. Gowan (Belmont, Massachusetts, U.S.A.) revised the English of this paper. Financial support from the Academy of Finland (project No. 1011799, 1991-1993) is gratefully acknowledged.

\section{References}

Ahti, T., Hämet-Ahti, L. \& Jalas, J. 1968: Vegetation zones and their sections in northwestern Europe. - Ann. Bot. Fennici 5:169-211.

Bondartsev, A.S. 1953: Trutovye griby evropeiskoi chasti SSSR i Kavkaza. - 1106 pp. Akad. Nauk SSSR, Moskva.

Bourdot, H. \& Galzin, A. 1928: - Hyménomycètes de France. Hetérobasidiés-Homobasidiés gymnocarpes. - 761 pp. Soc. Myc. France, Sceaux.

Breitenbach, J. \& Kränzlin, F. 1986: Fungi of Switzerland 2. Non gilled fungi. Heterobasidiomycetes, Aphyllophorales, Gasteromycetes. - 412 pp. Verlag Mykologia, Lucerne.

David, A. 1980: Étude du genre Tyromyces sensu lato: Répartition dans les genres Leptoporus, Spongiporus et Tyromyces sensu stricto. - Bull. Soc. Linn. Lyon 49:6-56.

Domanski, S. 1964: Tyromyces lowei (Pil. ex. Pil.) Bond. w Polsce. - Fragmenta Flor. Geobot. 10:81-88.

Domafiski, S. 1972: Fungi: Polyporaceae 1, Mucronoporaceae 1. - 235 pp. Foreign Scientific Publications, Warsaw.

Donk, M.A. 1960: The generic names proposed for Polyporaceae. - Persoonia 1:173-302.

Donk, M.A. 1972: Notes on European polypores 11. On some species of Tyromyces. - Proc. Koninkl. Nederlandsche Akad. Wetensch. (C) 75:287-304.

Donk, M.A. 1974: Check list of European polypores. - Verh. Koninkl. Nederlandsche Akad. Wetensch. Afd. Natuurk.,
Tweede Reeks 62:1-469.

Erkkilä, R. \& Niemelä, T. 1986: Polypores in the parks and forests in the City of Helsinki. - Karstenia 26:1-40.

Fries, E.M. 1828: Elenchus fungorum 1. -238 pp. Ernest Mauritius, Gryphiswaldiae.

Fries, E.M. 1874: Hymenomycetes Europaei. - 755 pp. Berlingius, Lundae.

Fries, E.M. (ed.) 1884: Icones selectae Hymenomycetum, nondum delineatorum 2. - 200 pp. Reg. Acad. Scient. Holmiensis, Holmiae \& Upsaliae.

Gilbertson, R.L. \& Ryvarden, L. 1985: Some new combinations in the Polyporaceae. - Mycotaxon 22:363-365.

Gilbertson, R.L. \& Ryvarden, L. 1987: North American polypores 2. Megasporoporia-Wrightoporia. - Pp. 434-885 Fungiflora, Oslo.

Greuter, W., Burdet, H.M., Chaloner, W.G., Demoulin, V., Grolle, R., Hawskworth, D.L., Nicolson, D.H., Silva, P.C., Stafleu, F.A., Voss, E.G. \& McNeill, J. 1988: International Code of Botanical Nomenclature. - Regnum Vegetabile 118:1-328.

Holmgren, P.K., Holmgren, N.H. \& Barnett, L.C. 1990: Index herbariorum 1. The herbaria of the world. 8th ed. Regnum Vegetabile 120:1-693.

Jülich, W. 1982: Notes on some Basidiomycetes (Aphyllophorales and Heterobasidiomycetes). - Persoonia 11:421-428.

Jülich, W. 1984: Kleine Kryptogamenflora 2b(1), Basidiomyceten 1. Die Nichtblätterpilze, Gallertpilze und Bauchpilze (Aphyllophorales, Heterobasidiomycetes, Gastromycetes). - 626 pp. Gustav Fischer Verlag, Stuttgart \& New York.

Koch, J. 1975: Aurantioporus alborubescens og A. fissilis på Fagus silvatica i Danmark. - Friesia 11:54 61.

Kotiranta, H. \& Niemelä, T. 1981: Composition of the polypore communities of four forest areas in southern Central Finland. - Karstenia 21:31-48.

Kotlaba, F. 1975: Revision of the polypores (Polyporales) described as new by J. Velenovský. - Acta Musei Nat. Pragae 31b:1-56.

Kotlaba, F. \& Pouzar, Z. 1964: Staronový choros Tyromyces gloeocystidiatus Kotl. \& Pouz. - belochoros nahorklý. Ceská Mykol. 18:207-218.

Largent, D., Johnson, D. \& Watling, R. 1977: How to identify mushrooms to genus 3. Microscopic features. - 148 pp. Mad River Press, Eureka.

Larsen, M.J. \& Lombard, F.F. 1986: New combinations in the genus Postia Fr. (Polyporaceae). - Mycotaxon 26:271-273.

Lowe, J.L. 1975: Polyporaceae of North America. The genus Tyromyces. - Mycotaxon 2:1-82.

Lowe, J.L. \& Lundell, S. 1956: The identity of Polyporus trabeus Rostk. - Pap. Michigan Acad. Sci. Arts Lett. 41:21-24 +Table 1.

Murrill, W.A. 1912: Polyporaceae and Boletaceae of the Pacific coast. - Mycologia 4:91-100.

Niemelä, T. 1985a: On Fennoscandian polypores 9. Gelatoporia n.gen. and Tyromyces canadensis, plus notes on Skeletocutis and Antrodia. - Karstenia 25:21-40.

Niemelä, T. 1985b: Mycoflora of Poste-de-la-Baleine, northern Québec. Polypores and the Hymenochaetales. - Naturaliste Canadien 112:445-472.

Niemelä, T. 1991: Suomen kääpien määritysopas. — Helsingin Yliop. Kasvitiet. Lait. Monist. 125:1-105.

Niemelä, T. \& Penttilä, R. 1992: Antrodia mellita (Basidiomycetes), a new large-pored polypore species with a continental distribution. - Ann. Bot. Fennici 29:55-65. 
Overholts, L.O. 1953: The Polyporaceae of the United States, Alaska, and Canada. - 456 pp. Univ. Michigan Press, Ann Arbor.

Parmasto, E. \& Parmasto, I. 1987: Variation of basidiospores in the Hymenomycetes and its significance to their taxonomy. - Bibl. Mycol. 115:1-168.

Pilát, A. 1936-1942: Polyporaceae I. - In Kavina, C. \& Pilát, A. (eds.), Atlas des Champignons de l'Europe 3:1-624, 374 pls. Privately published, Praha.

Pouzar, Z. 1967: Studies in the taxonomy of the polypores 3. Ceská Mykol. 21:205-212.

Pouzar, Z. 1984: Notes on four European polypores. — Ceská Mykol. 38:203-204.

Rassi, P., Kaipiainen, H., Mannerkoski, I. \& Ståhls, G. 1992: Uhanalaisten eläinten ja kasvien seurantatoimikunnan mietintö. Report of the monitoring of threatened animals and plants in Finland. Komiteanmietintö 1991:30. - 328 pp. Ympäristöministeriö, Helsinki.

Reid, D.A. \& Austwick, P.K.C. 1963: An annotated list of the less common Scottish Basidiomycetes (exclusive of rusts and smuts). - Glasgow Naturalist 18:255-336.

Renvall, P., Renvall, T. \& Niemelä, T. 1991a: Basidiomycetes at the timberline in Lapland 1. Introduction. - Karstenia $31: 1-12$.
Renvall, P., Renvall, T. \& Niemelä, T. 1991b: Basidiomycetes at the timberline in Lapland 2. An annotated check-list of the polypores of northeastern Finland. - Karstenia 31:13-28.

Ryvarden, L. 1978: The Polyporaceae of North Europe 2. Inonotus-Tyromyces. - Pp. 215-507. Fungiflora, Oslo.

Ryvarden, L. 1985: Type studies in the Polyporaceae 17. Species described by W.A. Murrill. - Mycotaxon 23:169-198.

Ryvarden, L. 1991: Genera of polypores. Nomenclature and taxonomy. - Synopsis Fungorum 5:1-363.

Teixeira, A.R. 1983: "Dura lex sed lex" - Correta determinacãode leptótipos de trinta generos de Polyporaceae. - Rickia 10:105-122.

Teixeira, A.R. 1986: Genera of Polyporaceae. - Rickia 13:133-202.

Vampola, P. 1991: Pómatka sevemí - Oligoporus septentrionalis, nový choros československé mykoflóry. - Česká Mykol. 45:144-149.

Received on 29 May 1992 